The purpose would be to give priority to lecturers and teachers who have a number of years of service ahead of them, and to relate teaching methods to the dynamic nature of advanced industrial techniques. The college should be able to provide opportunities for intensive short courses and conferences on the teaching of any aspect of technology at the more advanced levels.

\section{Radioactive Substances in Technical Colleges}

Technical colleges are expected to play their part in developing the use by industry of radioactive substances, X-rays and gamma-rays. Courses of instruction or research in these fields, however, call for special precautions on the part of the colleges to protect students and staff involved. In a recent memorandum to local education authorities, the Minister of Education advises the appointment of technically competent safety officers to be specifically responsible for advice on radiological protection in colleges where radioactive materials are used. The memorandum advises the use of separate laboratories, reserved solely for radioactive work; the provision of secure and adequately shielded storage places for radioactive substances, and the installation of mechanical ventilation where there is risk of radioactive gases. Other suggestions refer to the necessity of controlling removal of materials from storage, their transport from place to place and the disposal of radioactive wastes by methods which must be agreed with local authorities. Decontamination of equipment and clothing is also extremely important. Special precautions should be taken in the use of X-ray apparatus; and installations which are not completely protected should be placed in a separate room which should be unoccupied during exposure. The Minister refers particularly to the danger of exposure to gammo-rays. Because of the amount of protection required it may often be impossible to provide indoor accommodation in which operation can safely be carried out, and it may therefore be necessary to conduct gamma-radiography in the open air in a roped-off area. Colleges are asked to inform the Ministry before starting instruction or research in this field.

\section{The Palæontological Association}

ON January 30 , at a meeting attended by about seventy palæontologists and those interested in palæontology, it was resolved to form a Palæontological Association. An inaugural meeting was held on February 27 at the Imperial College of Science and Technology, at which a constitution was adopted and the following elected as council and officers for 1957: President, Dr. R. G. S. Hudson; VicePresidents, Dr. E. I. White and Mr. N. F. Hughes; Treasurer, Dr. W. S. McKerrow, Department of Geology, University Museum, Oxford; Editor, Dr. W. H. C. Ramsbottom; Secretary, Dr. F. Hodson, Department of Geology, University of Reading; Other Members of Council, Dr. F. W. Anderson, Dr. T. Barnard, Prof. O. M. B. Bulman, Dr. F. E. Eames, Mr. G. F. Elliott, Prof. T. N. George, Dr. Dorothy H. Rayner, Mr. P. C. Sylvester-Bradley, Dr. J. T' Temple, Dr. Gwyn Thomas, Prof. T. S. Westoll, Prof. W. T. Whittard, Prof. Alwyn Williams and Prof. A. Wood. The Association, which seeks support from all who are interested in palæontology, plans to hold discussion-meetings in London and other centres in Britain. It is intended that the Association's activities shall cover all aspects and branches of the subject. A journal is being planned. Membership can be obtained by paying an annual subscription of two guineas.

\section{Science in France}

UNDER the title "Scientific Information", the French Ministry for Foreign Affairs (Department of Cultural Relations) is issuing for free distribution to scientific organizations on request a bulletin summarizing recent scientific activities in France. The first issue (Informations Scientifique, No. 1, 1956. Pp. 52. Paris: Ministère des Affaires Etrangères) outlines the formation and organization of the National Centre for Scientific Research, the scope of scientific and technical research on potash in Alsace and the organization of the Society for Chemical Studies for Industry and Agriculture, which has a research centre at Argenteuil, and the new centre for biological and pharmaceutical research at Strasbourg. Some recent researches in French laboratories on nuclear physics and atomic energy, on poliomyelitis, on the synthesis of granite, etc., are briefly described. Following a section noting features in higher education in France and in the work of the Academy of Sciences, there is a useful annotated bibliography of French scientific works published in 1955 .

\section{The Art of Lecturing}

IN a short booklet Dr. G. Kitson Clark, of the University of Cambridge, points out that while the Army, civil defence authorities, various religious denominations, political parties and many other organizations provide training for their lecturers, it is not normal for a university to do so; the assumption is made that dons should be able to lecture by the light of Nature. To help those who are willing to learn, Clark sets out some valuable pointers drawn from his own experience on such topics as the content of subject-matter, the length of lectures, the stance and posture of the lecturer, the use of microphones and of the blackboard, voice production, the use of notes by the lecturer and the making of them by his audience. The booklet has been published by W. Heffer and Sons, Cambridge, price $1 s .6 d$.

\section{Klamath Prehistory}

THE Klamath area in Oregon adjoins the Great Basin, but differs from it in possessing a constant water supply, of which the effect on the life of the inhabitants is clearly shown in a report recently published (Trans. Amer. Phil. Soc., New Series, 46, Part 4: Klamath Prehistory-The Prehistory of the Culture of the Klamath Lake Area, Oregon. By L. S. Cressman, William G. Haag, and William S. Laughlin. Pp. ii +375-514. Philadelphia : American Philosophical Society, 1956. 2 dollars). In historic times the area was occupied by the Klamath Indians. In the course of four seasons work, Dr. Cressman accumulated the data which are the subject of the report. By excavation of house pits, going back from quite recent times to at least A.D. 1500, an earlier midden and a cave, he has traced a continuous occupation back to before a volcanic eruption which took place about 5500 B.c. Despite minor variations, the inhabitants of this region never progressed beyond a food-gathering and fishing economy. This is an interesting and well-illustrated account. The area it deals with is small and rather specialized, but the way in which the archæology is described and related to neighbouring areas gives it more than a local import- 